\title{
Challenges of mega construction projects in developing countries
}

\author{
Ayman Ahmed Ezzat Othman \\ Architectural Engineering Department, \\ Faculty of Engineering, \\ The British University in Egypt (BUE) \\ ayman.othman@bue.edu.eg
}

DOI 10.5592/otmcj.2013.1.10 Research Paper

\section{Keywords}

Mega Construction Projects, Challenges, Sustainable Development, Developing Countries.
Mega Construction Projects (MCPs) Represent a strategic OPTION TOWARDS ACHIEVING SUSTAINABLE DEVELOPMENT OBJECTIVES IN DEVELOPING COUNTRIES. On the one hand, these projects are charaterised with the need for high design knowledge and technical skills; competent human resources and managerial capabilities as well as excessive cost investment. Conversely, developing countries experience shortage of many of these requirements, which obstruct the development of (MCPs). This paper aims to identify, validate, and classify the challenges of delivering (MCPs) in developing countries. Towards achieving this aim, two approaches were employed, namely literature review and case studies, to accomplish four objectives.

- Reviewing the nature and characteristics of developing countries and (MCPs); identifying the challenges of delivering (MCPs) in developing countries and establishing the need for (MCPs) in developing countries.

- Validating the challenges identified from Litearture review through collecting and analysing 36 case studies of (MCPs) in developeding countries. Case studies confirmed many of the identified challenges and added new insights that were not covered in current literature.

- Classifying the identified clalenges into four categories: engineering challenges, human development challenges, managerial and political challenges and sustainability challenges.

- Outlining research conclusions and recommendations useful for delivering successful (MCPs) in developing countries. 


\section{INTRODUCTION}

Governments in developing countries, where approximately $85.4 \%$ of the world's population lives in, develop (MCPs) to achieve their social and economic sustainable development objectives (Human Development Report, 2011; Zeybek and Kaynak, 2006; Cohen, 2006). This is accomplished through constructing infrastructural, industrial, educational, cultural, transportational, medical, and residential projects that provide societies with their needs and fulfil their requirements (Othman, 2012; Khan, 2008; Mthalane et al., 2007; Field and Ofori, 1988). (MCPs) are complex, risky and time-consuming undertakings that are usually commissioned by governments and delivered by national and international participants with a variety of cultural differences, backgrounds, political systems, and languages (Shore and Cross, 2005). They attract high levels of public attention and political interest due to the substantial cost, direct and indirect impact on the community, environment, and budgets (Van Marrewijk et al., 2008; Capka, 2004). On the one hand and due to their unique nature and characteristics, (MCPs) require high design knowledge and technical skills, competent human resources, professional managerial capabilities and large-scale investment (Sturup, 2009; Frick, 2006; Flyvbjerg, et al., 2003). In contrast, developing countries suffer from having shortage in providing these essential knowledge, skills, capabilities, and finance, which ultimately challenge the development of (MCPs). Towards assisting governments in developing countries achieving their sustainable development objectives, this paper aims to identify, validate and classify the challenges of delivering (MCPs) in developing countries.

\section{Research Objectives and Methodology}

To achieve this aim, a research methodology, consists of literature review and case studies, is developed to accomplish four objectives.
Firstly, building a comprehensive background of the research topic including (1) nature and characteristics of developing countries and (MCPs), (2) identifying of challenges of (MCPs) in developing countries and underlining the necessity of (MCPs) in developing countries as an approach for achieving sustainable development objectives. This objective was achieved through literature review depending on textbooks, academic journals and professional magazines, conference and seminar proceedings, dissertations and theses, organisations and government publications as well as Internet and related websites.

- Secondly, validating the challenges identified from literature review through collecting and analysing 36 case studies of (MCPs) (either completed, under development, on hold or cancelled) in developing countries worldwide. The use of case studies confirmed many of the identified challenges and added new insights, which were not covered by current literature. These new insights were specific to the culture of the analysed projects and their societies. Although, literature review and case studies confirmed 31 out of 45 challenges, which highlighted their importance and increased their credibility, other challenges that were merely identified by literature review are also of value to construction literature. By using more than one source of evidence (literature review and case studies), it was possible to improve the validity of the collected challenges and increase background knowledge. In an effort to ensure the reliability of the data, data collection concentrated on facts and events, rather than highly subjective interpretations (Yin 1989; MacPherson et. al 1993). Literature review and case studies resulted in the identification of 65 challenges of delivering (MCPs) in developing countries. The work was reviewed and refined by the author on regular basis to omit repeated challenges and merge similar ones. The result was 45 challenges.

Thirdly, classifying the challenges of (MCPs) based on their nature into four categories, namely Engineering Challenges, Human Development Challenges, Managerial and Political Challenges, and Sustainability Challenges.

- Finally, outlining research conclusions and recommendations useful to delivering (MCPs) in developing countries.

\section{Case Study Sampling}

The objective of case study sampling was to select a representative and nonbiased sample of (MCPs) from which to identify the challenges that obstruct their development in developing countries. (MCPs) is a new area of research in construction literature (Brockmann and Girmscheid, 2007). In addition, the interest of the research community in megaprojects has begun to grow (e.g. the International Journal of Project Management's special issue on "Complexities in Managing Mega Construction Projects," October 2011 and Organization, Technology and Management in Construction: An International Journal's special issue on “Megaproject Management," December 2012). As a result, many areas of megaproject management remain largely uncharted such as challenges of their delivery in developing countries, which made it difficult to select the case study sample and obtain relevant resources. To overcome this issue, the principal list of (MCPs) developed worldwide was collected from available literature and related websites which consisted of (348) projects. The collected projects excluded non-construction projects such as (Information Technology, Military, Science, Oil and Gas projects) as they are beyond the scope of this research. Once the list has been com- 


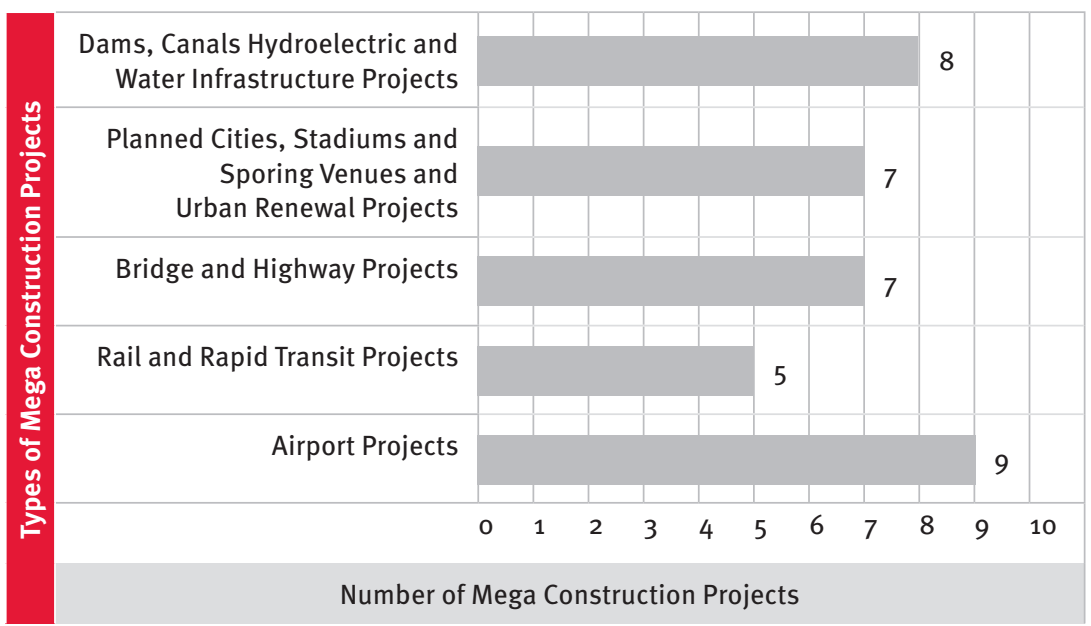

Figure 1 Types and Numbers of Surveyed (MCPs) in Developing Countries

piled, the (MCPs) (either completed, under development, on hold or cancelled) in developing countries were extracted which were 100 projects. Due to lack of resources and difficulty accessing information regarding these projects, only 36 case studies were successfully collected and analysed, representing $36 \%$ of (MCPs) projects in developing countries. Detailed information focused on project's type, location, cost, duration, and challenges. This sampling methodology has, effectively covered developing countries worldwide, so the identified challenges were extracted from different projects constructed in different countries, with different scope, regulations, client organisations, cost, duration, all of which enhanced the reliability and validity of the identified challenges, see figure (1) and table (1) in appen$\operatorname{dix}(A)$.

\section{Literature Review}

\section{Overview and Characteristics of Developing Countries}

The distinction between "developed" and "developing" countries is a continuous issue and is surrounded by fierce debate (Moohebat et al., 2010). Generally, the classification of a country as "developed" or "developing" is based on certain measures such as
(1) economic development, (2) education and training provision, (3) political stability, technological development, infrastructure and production rate, (4) healthcare, life expectancy and growth rate of population, and (5) society, demography and culture issues. Economically, the World Bank (2012) classified countries into four income groups based on their Gross National Income (GNI) per capita. All low, lower, and upper middle-income countries are classified as developing countries as follows:

$\checkmark$ Low income countries

GNI $\leq$ US\$1,025 per capita

- Lower middle income countries $\mathrm{GNI}=$ US $\$ 1,026$ - US\$ 4,035 per capita

- Upper middle income countries $\mathrm{GNI}=$ US $\$ 4,036$ - US\$12,475 per capita

$>$ High income countries

$\mathrm{GNI}=\mathrm{US} \$ 12,476$ and above per capita

Recently the United Nations (UN) developed another measure, the Human Development Index (HDI), which combines there basic dimensions of human development, namely "long and healthy life", "knowledge” and "decent standard of living", to gauge the level of human development of countries (Human Development Report, 2011) as follows.
Low human development HDI below 0.500

> Medium human development $\mathrm{HDI}=0.500-0.799$

$\checkmark$ High human development $\mathrm{HDI}=0.800-0.899$

$\checkmark$ Very high human development $\mathrm{HDI}=0.90$ and above

$52 \%$ of the world's population live in countries with "medium human development," while $18 \%$ populate countries falling in the "low human development" category. Countries with "high" to "very high" human development account for $30 \%$ of the world total population. Table (2) summarises the remaining characteristics of developing countries.

Nature and Characteristics of (MCPs) Different terms are used in literature to describe large projects such as complex projects, major projects, giant projects, new animals and megaprojects (Ruuska et al., 2009; Grun, 2004; Flyvbjerg, et al., 2003). While such projects are large, they are not unparalleled in history (Brockmann and Girmschied, 2007). There are several different statements that claim to be a definition of (MCPs) and there are different perspectives on what (MCPs) are. However, all these definitions and perspectives agree that (MCPs) are huge investment projects aimed at supporting governments achieving their social and economic development objectives. (MCPs) attract public and political attention due to their substantial impacts on communities, environment and budgets (Van Marrewijk et al., 2008; (apka, 2004). In addition, (MCPs) are owned by governments and executed by large construction firms. Furthermore, (MCPs) are risky undertakings that consume substantial amount of time, cost and requires highly trained design and construction professionals as well as skilled managerial team. Table (3) summarises the characteristics of (MCPs). 
Characteristics related to Education, Training and Brain Drain

\begin{tabular}{l|l}
1 & Low standard of education and vocational training
\end{tabular}

$2 \quad$ Out flow of best brains

(Connexions, 2012; WDR, 2012; Kumar, 2012; Economics, 2010; Kintu, 2008)

Characteristics related to Policy, Economy, Technology, Infrastructure and Production

\begin{tabular}{|l|l|}
\hline 3 & Corruption and political instability \\
\hline 4 & Lack of capital and technology \\
\hline 5 & Dualistic economy \\
\hline 6 & Vicious Circle of Poverty \\
\hline 7 & Low levels of productivity \\
\hline 8 & Inequalities of national income distribution \\
\hline 10 & Inadequate infrastructure \\
\hline 11 & Heavy dependence on agricultural production \\
\hline 12 & Lack of industries and enterprises \\
\hline 13 & Underutilized natural resources \\
\hline 14 & High and rising levels of unemployment and under-employment \\
\hline
\end{tabular}

(Economic Concepts, 2013; Connexions, 2012; Kumar, 2012; Economics, 2010; Bobrova and Kalvina, 2004; Fry, 1998)

Characteristics related to Health Care, Life Expectancy and Growth Rate of Population

\begin{tabular}{l|l}
15 & Poor health care \\
\hline 16 & Low life expectancy \\
\hline 17 & High rates of population growth and dependency burdens \\
\hline
\end{tabular}

(Economic Concepts, 2013; WDR, 2012; Connexions, 2012; Kumar, 2012)

Characteristics related to Society, Demography and Culture

\begin{tabular}{|l|l|}
\hline 18 & General and social backwardness \\
\hline 19 & Demographic characteristics \\
\hline 20 & Socio-cultural characteristics \\
\hline
\end{tabular}

Table 2 Characteristics of Developing Countries

\section{Identification of Challenges of delivering (MCPs) in developing countries}

In order to assist developing countries achieving their sustainable development objectives and overcoming the challenges that hinder the development of (MCPs), these challenges have to be identified. Literature review and case studies identified 65 challenges of developing (MCPS) in developing countries. These challenges were reviewed and refined by the author on regular basis to omit repeated challenges and merge similar ones. The result was 45 challenges. Table (4) lists the identified challenges and indicated whether these challenges were identified from literature, case studies or both.

\section{Classification of Challenges of delivering Megaprojects in developing countries}

Based on their nature, the identified challenges were classified into four categories, namely, (1) Engineering Challenges, (2) Human Development Challenges, (3) Managerial and Political Challenges and (4)) Sustainability Challenges. Because of the fact that many challenges resulted from more than one factor, many of these challenges fall under more than one classification category, see table (5) in appendix (B).

The Rationale behind the Challenges of Developing(MCPs) in Developing Countries
Many of the challenges that were identified through literature review were confirmed by analysis of the case studies as shown in table (2). These challenges can be classified into 4 categories and the rationale behind their occurrence investigated in order to identify their impact on developing (MCPs) in developing countries.

\section{Rationale behind Engineering}

Challenges (No's. 1, 2, 3, 5, 20, 22, $23,24,36,37,38,42$ \& 45)

Engineering challenges that face the development of (MCPs) in developing countries are classified as design challenges and technical challenges. Due to their nature, the development of 


\begin{tabular}{|c|c|c|}
\hline 1 & $\begin{array}{l}\text { Colossal in size and scope physical infrastructure / capital asset with a life span measured in decades } \\
\text { in order to plan, design, finance and build }\end{array}$ & $\begin{array}{l}\text { (Sanderson, 2012; Sturup, } \\
\text { 2009; Frick, 2006; Bruzelius } \\
\text { et al., 2002) }\end{array}$ \\
\hline 2 & Located in remote and/or inhospitable areas & $\begin{array}{l}\text { (Flyvbjerg, et al., 2003; Haynes, } \\
\text { 2002). }\end{array}$ \\
\hline \multirow{3}{*}{3} & $\begin{array}{l}\text { Costly and often under estimated projects that require high investment expenditures of: } \\
\text { US\$1 billion or more }\end{array}$ & $\begin{array}{l}\text { (Sturup, 2009; Frick, 2006; } \\
\text { Flyvbjerg, et al., 2003; Bruzelius } \\
\text { et al., 2002) }\end{array}$ \\
\hline & f150 million as a bench mark cost & (Sturup, 2009) \\
\hline & EUR 0.5 billion and more & (Megaproject Cost Action, 2012) \\
\hline 4 & Controversial and often have financing difficulties & $\begin{array}{l}\text { (Sturup, 2009; Frick, 2006; } \\
\text { Haynes, 2002) }\end{array}$ \\
\hline \multirow{5}{*}{5} & $\begin{array}{l}\text { Risky undertakings, especially when: } \\
\text { project priorities and objectives changed }\end{array}$ & (Ruuska et al., 2009) \\
\hline & project extends over its economic cycles & (Jia et al., 2011; little, 2011) \\
\hline & shortage of labour and suppliers & (Haynes, 2002) \\
\hline & lack of planning and cost estimate & $\begin{array}{l}\text { (Keegan, 2004; Bruzelius } \\
\text { et al., 2002) }\end{array}$ \\
\hline & poor technology and traditional delivery methods & (Jia et al., 2011; little, 2011) \\
\hline \multicolumn{3}{|c|}{ Characteristics related to Client(s) and Performing Organisation Structure } \\
\hline 6 & The client is often a government or public sector organisation & (Kardes, et al., 2013; \\
\hline 7 & $\begin{array}{l}\text { The main contractor or consortium of contractors are usually privately owned, financed } \\
\text { and often from various countries with variety of cultural differences, backgrounds, } \\
\text { political systems, and languages, seeking success with different objectives }\end{array}$ & $\begin{array}{l}\text { Sanderson, 2012; Ruuska et al., } \\
\text { 2009; Shore and Cross, 2005; } \\
\text { Haynes, 2002 ) }\end{array}$ \\
\hline 8 & $\begin{array}{l}\text { Complex management structure and the matrix and project organisational forms } \\
\text { are used interchangeably }\end{array}$ & $\begin{array}{l}\text { (Kerzner, 2003; Stoddart- } \\
\text { Stones, 1988). }\end{array}$ \\
\hline 9 & Insufficient experience of performing organisation in managing complex undertakings & (Keegan, 2004; Haynes, 2002) \\
\hline 10 & $\begin{array}{l}\text { Continuous organizational restructuring may be necessary as each } \\
\text { project goes through a different life-cycle phase }\end{array}$ & (Kerzner, 2003) \\
\hline
\end{tabular}

\begin{tabular}{|c|c|c|}
\hline 11 & $\begin{array}{l}\text { The performing company often retains an ownership stake in the project after completing the } \\
\text { construction phase in a special purpose vehicle and is paid by the client for the service that flows } \\
\text { from the asset's operation or use over a number of years }\end{array}$ & (Sanderson, 2012) \\
\hline \multicolumn{3}{|c|}{ Characteristics related to Engineering Design and Technical Requirements } \\
\hline 12 & $\begin{array}{l}\text { Complex projects that demand high design knowledge, professional } \\
\text { technological skills and logistical support }\end{array}$ & \multirow{2}{*}{$\begin{array}{l}\text { (Sturup, 2009; Frick, 2006; } \\
\text { Flyvbjerg, et al., 2003) }\end{array}$} \\
\hline 13 & Necessitates multidisciplinary contributions from various organizations & \\
\hline 14 & $\begin{array}{l}\text { Long termed projects that require program planning, control and highly } \\
\text { trained employees especially in the field of Project Management }\end{array}$ & \multirow{3}{*}{ (Sturup, 2009; Kerzner, 2003) } \\
\hline 15 & Requires clearly defines rules and procedures as well as effective communication at all levels & \\
\hline 16 & Requires quality front-planning & \\
\hline 17 & $\begin{array}{l}\text { Projects' captivation due to their size, engineering achievements and aesthetic design } \\
\text { call for virtual enterprise for the implementation of the project through } \\
\text { exploiting fast-changing opportunities and confronting problems as early as possible }\end{array}$ & $\begin{array}{l}\text { (Sturup, 2009; Frick, 2006; } \\
\text { Flyvbjerg, et al., 2003) }\end{array}$ \\
\hline \multicolumn{3}{|c|}{ Characteristics related to Environment, Society, Economy and Policy } \\
\hline 18 & Public acceptance / opposition due to the social, economic, political and environmental impacts & $\begin{array}{l}\text { (Ruuska et al., 2009; Haynes, } \\
\text { 2002) }\end{array}$ \\
\hline 19 & $\begin{array}{l}\text { Politics are playing an important role in how senior management } \\
\text { appointments and activities are defined. }\end{array}$ & $\begin{array}{l}\text { (Haynes, 2002; Stoddart- } \\
\text { Stones, 1988) }\end{array}$ \\
\hline 20 & Poor risk analysis and inappropriate identification of the project consequences & (Hopkinson, 2007) \\
\hline
\end{tabular}


(MCPs) requires unique design knowledge, skills, and experience. Lack of professional expertise, shortage of full understanding of scientific and technical requirements (Georgieva, 2012) and improper decisions and overlooking specialists and stakeholders consultation during the decision making process (Kerzner, 2006; Jia et al., 2011) obstruct the development of (MCPs) in developing countries. These challenges were clearly noticed in Toshka project, a water infrastructure development, Egypt as not all technical requirements have been taken into full consideration and the different studies conducted over the years related to the project have not been discussed openly and in public, see figure (2). Examples of the technical failure include:

- The high level of saline in the Western Desert's and the presence of underground aquifers acted as a major hindrance to any irrigation project. As the land is irrigated, the salt mixes with the aquifers and reduces access to potable water.

- The clay minerals found in the soil are also posing technical problems to the big-wheeled structures moving around autonomously to irrigate the land. These wheels get stuck in a little bowl created by wet clay that dried, and the irrigation machines come to a standstill (Deputy, 2011).

- One of the main problems that affect the performance of the Great Manmade River in Libya is the rust of water pumps and corrosion of steel pipes installed in this project. This is a result of ignoring the warning of the specialised Danish provider of the equipment about the excessive use of chlorine in water purification. Consequently, the project administration decided to reduce the water pressure in these pipes and looked for replacing the installed pumps.

- Lack of design experience and poor management capabilities play a significant role towards misunder- standing client requirements and incomplete achievement of project objectives (Georgieva, 2012). In addition, these shortcomings have negative impact on the project through specifying materials that are outdated, no longer produced or available in the market (Tenah, 1985). In turn, project stakeholders change project requirements at later stages of the project life cycle. An example of these challenges is in a case study of 400 housing projects designed by a foreign consultant, who did not adequately understand the culture and traditions of the endusers. After the practical completion stage of the project, the users carried out significant changes in order to meet their requirements such as privacy and the ability to add more rooms for future increase in their family sizes (Othman et al., 2004).

- Lack of research capacity for addressing contemporary social and environmental problems as well as lack of private business investment in innovation and providing new and improved processes and product hinders the development of (MCPs) in developing countries (Georgieva, 2012). This is because the private sector has the potential and experience towards assisting governmental organisations achieving sustainable development objectives (Othman and El-Gendawy, 2012).

> Strategic project planning, effective leadership and proper application of project management knowledge and skills as well as utilising the experience and competency of client and contractor organisations enabled a small group of Malaysian Professionals to deliver successfully Kuala Lumpur International Airport (KLIA) project to the Government of Malaysia within seven years from the word 'go' at lower cost by Ringgit Malaysian 11 billion ( RM $1=$ US\$ 0.32) with full commitment on time completion without sacrificing architectural beauty, functionality and quality. Professional project managers were able to manage complexity and run 205 different contract packages concurrently and deliver the first ever airport to successfully develop, design and implement a fully integrated IT airport management system (Hussein and Karimin, 2006).

- Kerzner (2006) stated that improperly defined rules and procedures and shortage of using prior experience to review contingencies obstruct the achievement of (MCPs) objectives in developing countries. This is because these challenges lead to loss of effort and responsibility as well as manage unforeseen events. In addition, poor quality front-end planning can deteriorate the whole quality management process and lead to delivering projects that do not meet client and user expectations.

\section{Rational behind Human}

\section{Development Challenges}

(No's. 8, 11, 12, 15, 17, 18 \& 43)

- The ability to attract, retain and develop talented employees is a key feature of successful business. People are an organisation's most valuable asset and this is especially true in relatively low-tech, labourintensive industries such as construction (Loosemore et al., 2003). Labours are the lifeblood of any construction project, especially (MCPs) in developing countries. They are the workforce that creates the final product. Therefore, it is imperative to improve their skills and enhance their abilities to increase the productivity of the construction industry and ensure the quality of the constructed projects (Ramburan and Othman, 2007).

Shortage of providing quality education and professional training programmes is a major challenge that leads to lack of providing (MCPs) with high-qualified human resources, which have the right skills that match 
with project demands and geography. In addition, lack of human resources development in management related disciplines (i.e. project management, contract administration, leadership) results in poor supply of experienced staff who can accept critical roles, which they are not, prepared for (Georgieva, 2012). Furthermore, there is an agreement between academics and professionals that academic institutions do not equip graduates with necessary skills required to meet the requirements of the construction industry (Nkado, 2000; Chileshe and Haupt, 2007; Rwelamila, 2007) which highlights the need for human resource development.

> The construction of the 2010 FIFA World Cup stadia in South Africa is a clear example that explains the impact of the shortage of skilled labour on delivering (MCPS) in developing countries. Baloyi and Bekker (2011) stated that shortage of skilled labour was ranked the third out of nine causes of cost overrun (with Relative Importance Index $=0.58$ out of 1 ) and the second out of nine causes of time delays (with Relative Importance Index $=0.63$ out of 1 ).

> Another example is the development of Nelson Mandela Bay Metropole in South Africa where 100,000 specially designed dwellings of high architectural and engineering quality need to be constructed in 3-5 years to wipe out the backlog 2 million homes. Failing to provide skilled labour and properly trained on-site supervisors who are capable to deliver the required standard of work leaving delivery of homes to unreliable contractors was a major challenge towards achieving the project objectives (Koen and Theron, 2008).

\section{Rationale behind Managerial} and Political Challenges

(No's. 4, 6, 7, 9, 10, 12, 13, 16, 19,
21, 23, 24, 25, 26, 27, 28, 29, 30,

$31,32,34,35,39 \& 44)$

- Al-Maghraby (2012) and Georgieva (2012) stated that "Bureaucracy and corruption practices", "Lack of political support" and "Leadership problems" are main challenges of delivering (MCPs) in developing countries. When the country's leadership lacks vision of the future, careless, selfish, bureaucratic and corrupted, it opens the gate of stealing the economy, losing and depressing people, and lacking of control on the future. In addition, cor-ruption practices create a business environment unfavourable to innovation. Failing to develop (MCPs) prevent developing countries form promising projects that could take the whole country to new levels. Some examples that ascertain these challenges are:

- The Egypt - Saudi Arabia Bridge which supposed to be inaugurated back in 2007, was unexpectedly cancelled by the government without explanation, despite the offered funds from the Saudi side.

- The Western Desert New Axis Project that proposed a geography reformation project in order to help spreading the condense around the Nile valley through constructing a new axis, extending from Nasser lake to the Mediterranean sea by building a high transportation way, railroad, electricity stations, multiple horizontal connections with the original valley, was halted.

- Egypt Space Programme which started decades ago was an ambitious program for space scientific activities to put Egypt on the space map was stalled due to funding issues, careless and inattentive behavior of those supervising the programme.

- The lack of political support and inefficiency freezed the development of Chile's biggest multi-dam project (Merco Press, 2013) and delayed the Bandra-Worli Sea Link project, India about 5 years and increased its cost by $430 \%$.

> Political stability is the key to social and economic development in any country. It is vital for attracting foreign investment and constructing development projects (Dollerya and Worthingtonb, 1996). East Asian countries such as Malaysia, Thailand and Singapore registered sustained economic growth rates largely due to substantial foreign investment flows (Mansur et al., 2011). As an example of the negative impact of political instability on (MCPs) development is shown in the tensions between Turkey, Syria and Iraq which is raised from time to time due to South-eastern Anatolia Project (SAP) initiated in Turkey. Syria and Iraq demanded more water to be released, while Turkey declined so as to form the dam reservoirs. Almost came to a complete halt in the early 1990 due to the high level of Kurdish terrorists' activities in the region. The Kurdish activities are not only blamed for a number of funding cuts as funds were diverted to support the counter-terrorism effort, but is also blamed for damaging several dams and canals, as well as killing engineers working at the dams (GAP, 2011). Another example is Lahore Ring Road, Pakistan, where changes in government and lack of professional capabilities of governmental departments caused delay, change in project requirements and shot up the estimated cost.

In addition, political imperatives and authority misuse through laying of public funded projects in the hands of politicians accompanied with the pressure forced by project authorisation on individuals obstruct the development of (MCPs) in developing countries (Hopkinson, 2007). According to Toor and Ogunlana (2006), a number of challenges have been raised during the development of the Second Bangkok International Air- 
port, Thailand such as poor communication and coordination interface management between project stakeholders due to language barrier; lack of experience of project team; difference in local construction practices; lack of cooperation of government agencies; lack of foremen's experience and knowledge and bureaucratic behaviour of the employer. This necessitated that different leadership styles such as revolutionary, resolving, reverent and rewarding could be used to improve the skills of managers of (MCPs).

$\checkmark$ Lack of government decisions to strike a balance between short- and long-term objectives and effective risk mitigation (Procaccini et al., 2012) resulted in constructing the Long Thanh International Airport, Vietnam during the Vietnam War in a crowded neighbourhood to support war transportation and hence future expansion is limited and unsafe.

\section{Rationale behind Sustainability}

Challenges (No's. 4, 6, 14, 18, 19, 21 , $25,30,33,35$ \& 40)

- "Lack of financial resources, cost control and venture capital" is a common challenge that hinders the development of (MCPs) in developing countries (Georgieva, 2012; Jia et al., 2011). This issue is a result of low country's Gross Domestic Product (GDP), lack of financial resources and poor management of country's assets. Suramadu Bridge, Indonesia and Toshka project, Egypt are two examples of this challenge. While the construction of the first project began on 2003 by a consortium of Indonesian and Chinese companies with a total cost of US\$445 million (Witular, 2009), the bridge was halted at the end of 2004 due to lack of funds, but was restarted and completed by 2009. Likewise, while Toshka's total budget has been estimated to be US\$ 87 billion, Deputy (2011) stated that less than $25 \%$ of the original budget has been spent already, but the results are piecemeal. Astonishingly, a feasibility study of the project was only prepared in May 1998, about 17 months after establishing of the project (The Egyptian Gazette, 2011).

- Russky Bridge, Russia is an example of the challenge of "naïve risk analysis and inappropriate identification of the project consequences" (Hopkinson, 2007). The bridge was widely criticized by Russian political opposition as the cost of the bridge is three-times more than the budget of preparing the city of Primorsky Krai to host Asia-Pacific Economic Cooperation (APEC) Leaders' Summit. One the one hand, the project costs US $\$ 1$ billion and services a population of only 5,000 inhabitants. On the other hand, the throughput of the bridge is 50,000 cars per day which many times exceed the existing population. Another criticism of the project is the fact that the paved road ends in a dead end just beyond the bridge when local residents who live on the other side of the island have no access to telephones, public lighting or running water (CBC News, 2012).

- Being the largest earth filled dam in the world and second largest by the structural volume, the construction of Tarbela Dam, Pakistan in 1976 submerged 135 villages, which resulted in displacement of a population of about 96,000 people. Although a cash compensation of Rs 469.65 million (Rs $1=$ US\$ 0.01015 ) was paid to the affected people, the absence of a national policy showed that many affected of the project have still not been settled and not been given land as compensation by the Government of Pakistan as agreed with the World Bank (Pakistan \& Gulf Economist, 1999).

$\checkmark$ Lack of considering environmental requirements, preserving historical sites, and natural reserve are sustainability challenges that face the development of (MCPS) in developing countries. Amongst the projects that threaten the environment and endanger the biodiversity and historical sites are the (MCPs) being developed in Ethiopia (Walta info, 2013), Lakhta Centre, St. Petersburg, Russia (UNESCO, 2012), Belo Monte Dam, Brazil (Fearnside, 2006) and Cahora Bassa Dam, Mozambique (Beilfuss and dos Santos, 2011). Positively, the Mexico's government cancelled a controversial mega-resort development in Baja California Sur after environmentalists stated that it would have threatened a large coral reef in the Sea of Cortes that has rebounded dramatically from years of damage (Hernandez, 2012). Another example that shows the inappropriate identification of project consequences is the cultural damage that resulted from the vibration caused by the Tehran Metro, Iran to historic sites such as Golestan Palace and the national museum of Iran.

Lack of managing social complexity in terms of accepting the project by the community in which the project is intended to serve and the large number of project participants with different culture, knowledge and skills as well as diverse objectives is a challenge that affects the development of (MCPS) in developing countries. This challenge is reinforced by poor working condition, ignoring health and safety considerations as well as the absence of activating health and safety acts, which have dire social and economic consequence (Othman, 2012). One example that explains this issue is the re-location of the Kuala Namu International Airport, Indonesia to a more appropriate site away from residential areas due to crash of a flight in 2005 causing the death of officials and residents in areas around the airport area. 
1 Lack of design knowledge and experience related to (MCPs) (Georgieva, 2012; Deputy, 2011).

$\mathrm{X}$

$\mathrm{X}$ 2012; Deputy, 2011).

$x$ Misunderstanding and partial achievement of project objectives (Georgieva, 2012)

Cases $(1,9,16$
$19 \& 22)$
2012; Jia et al., 2011; Witular, 2009)

$5 \quad$ Lack of research capacity and business innovation (Georgieva, 2012)

$\mathrm{X}$

$6 \quad$ Missing Intermediary bodies (Georgieva, 2012)

$\mathrm{X}$

7 Unfavourable regulatory framework (Georgieva, 2012)

$x$

$8 \quad$ Lack of providing and managing high-qualified human resources (Georgieva, 2012; Baloyi and Bekker, 2011; Koen and Theron, 2008)

$\mathrm{X}$

Cases (11\&12)

9 Bureaucracy and corruption practices (Al-Maghraby, 2012; Georgieva, 2012)

$\mathrm{X}$

Case (17)

10 Lack of political support and inefficiency (Merco Press, 2013, Al-Maghraby, 2012; Georgieva, 2012)

$x$

Cases (2,9, $10,17,20 \& 22)$

11 Difficulty resourcing the right skills and matching with project demands and geography (Procaccini et al., 2012; Baloyi and Bekker, 2011).

$\mathrm{X}$

Case (11) al., 2012; Koen and Theron, 2008)
Lack of experienced staff to accept critical roles which they are not prepared for (Procaccini et

$\mathrm{X}$

$x$ effective risk mitigation (Procaccini et al., 2012)
Case (12)

Case (34)

$\mathrm{X}$

Case (15) phases (Procaccini et al., 2012)

15 Tight service market and lack of internal capacity (Procaccini et al., 2012)

$\mathrm{X}$

16 Improper implementation of project management processes and training of key project staff (Procaccini et al., 2012; Hussein and Karimin, 2006)

$\mathrm{X}$

Case (29)

17 Lack of available on-site skilled workers or local labour forces (Baloyi and Bekker, 2011; Kerzner, 2006)

18

Lack of properly trained on-site supervisors (Koen and Theron, 2008; Kerzner, 2006;)

$x$

Case (11)

Huge numbers of people and organisations of different specialties involved in mega projects development (Kerzner, 2006)

20 Ill-defined rules and procedures as well as inappropriate use of prior experience to review contingencies (Kerzner, 2006)

21 Inadequate communication at all levels and poor coordination interface management between project stakeholders (Kerzner, 2006; Toor and Ogunlana, 2006)

22 Lack of quality front-end planning (Kerzner, 2006)

$\mathrm{X}$

Case (12)

$x$

$\mathrm{X}$

X Cases (28\&31)

$\mathrm{x}$

23 Improper decision making and overlooking specialists and stakeholders consultation during the decision making process (Jia et al., 2011; Kerzner, 2006; Toor and Ogunlana, 2006).

$\mathrm{X}$

Case (28)

24 Lack of construction material availability (Tenah, 1985)

$\mathrm{x}$

25 Ignorance of health and safety considerations as well as the absence of activating health and safety acts (Othman, 2012)

\section{$\mathrm{X}$}

Case (31)

$\mathrm{X}$

Case (29) 


\begin{tabular}{|c|c|c|c|}
\hline 27 & Political imperatives and authority misuse (Hopkinson, 2007; Toor and Ogunlana, 2006) & $\mathrm{x}$ & Cases $(8 \& 28)$ \\
\hline 28 & Lack of exploiting uncertainties (Hopkinson, 2007) & $\mathrm{x}$ & \\
\hline 29 & Project authorisation pressures on individuals (Hopkinson, 2007) & $\mathrm{X}$ & \\
\hline 30 & Failure to invest sufficiently before the project's main authorisation point (Hopkinson, 2007) & $\mathrm{x}$ & \\
\hline 31 & Unachievable targets cause sub-optimal project outcomes (Hopkinson, 2007) & $\mathrm{x}$ & \\
\hline 32 & $\begin{array}{l}\text { Lack of efficiency and effectiveness of the Project Management process (Hopkinson, 2007; } \\
\text { Hussein and Karimin, 2006) }\end{array}$ & $\mathrm{X}$ & Case (29) \\
\hline 33 & $\begin{array}{l}\text { Naïve risk analysis and inappropriate identification of the project consequences (CBC News, } \\
\text { 2012; Hopkinson, 2007) }\end{array}$ & $\mathrm{X}$ & Cases $(18,27)$ \\
\hline 34 & $\begin{array}{l}\text { Inappropriate behaviour of the client organisation (Altman, 2005) and absence of national } \\
\text { policy to resettlement of affected people }\end{array}$ & $\mathrm{X}$ & Case (6) \\
\hline 35 & $\begin{array}{l}\text { Lack of considering environmental requirements, preserving historical sites, and natural } \\
\text { reserve (Walta info, 2013; UNESCO, 2012; Hernandez, 2012; Fearnside, 2006; Best \& De } \\
\text { Valence, 1999) }\end{array}$ & $\mathrm{X}$ & $\begin{array}{l}\text { Cases }(3,5,7 \\
13,14 \& 17)\end{array}$ \\
\hline 36 & $\begin{array}{l}\text { Ineffective project management and poor use of experience and competency of client and } \\
\text { contractor organisations (Hussein and Karimin, 2006) }\end{array}$ & $\mathrm{x}$ & Case (29) \\
\hline 37 & $\begin{array}{l}\text { Lack in managing complexities of work content and work processes (Hussein and Karimin, } \\
\text { 2006) }\end{array}$ & $\mathrm{X}$ & Case (29) \\
\hline 38 & Lack of strategic project planning and ineffective leadership (Hussein and Karimin, 2006) & $\mathrm{x}$ & Case (29) \\
\hline 39 & Leadership problems (Merco Press, 2013; Al-Maghraby, 2012) & $\mathrm{X}$ & $\begin{array}{c}\text { Cases } \\
(2,9,10 \& 17)\end{array}$ \\
\hline 40 & Lack of managing social project complexity (Brockmann and Girmschied, 2007) & $\mathrm{x}$ & \\
\hline 41 & $\begin{array}{l}\text { Lack of managing cultural project complexity (Brockmann and Girmschied, 2007; Othman et } \\
\text { al., 2004) }\end{array}$ & $\mathrm{X}$ & Case (15) \\
\hline 42 & $\begin{array}{l}\text { Inappropriate level of scientific and technological knowledge and application required (Jia et } \\
\text { al., 2011; Deputy, 2011) }\end{array}$ & $\mathrm{X}$ & Case (1) \\
\hline 43 & $\begin{array}{l}\text { Lack of providing quality education and professional training programmes (Baloyi and Bekker, } \\
\text { 2011; Naidoo et al., 2009) }\end{array}$ & $\mathrm{X}$ & Cases $(11 \& 12)$ \\
\hline 44 & Political tension between countries (GAP, 2011) & $\mathrm{x}$ & Case (4) \\
\hline 45 & $\begin{array}{l}\text { Stakeholders change project requirements at later stages of the project life cycle (Othman et } \\
\text { al., 2004) }\end{array}$ & $x$ & Case (15) \\
\hline
\end{tabular}

Table 4 Challenges of (MCPs) in Developing Countries

\section{CONCLUSIONS AND RECOMMENDATIONS}

This paper investigated the characteristics of developing countries and (MCPs) and aimed to identify, validate and classify the challenges that encounter the development of these projects in developing countries. Governments in developing countries construct (MCPs) as a strategic means for achieving sustainable development objectives such as infrastructure, healthcare facilities, educational institutions, human and economi- cal development projects. On the one hand, (MCPs) require high design knowledge and technical skills; competent human resources and managerial capabilities as well as high cost investment. On the other hand, developing countries are characterised with (1) low standard of education, training and out flow of best brains, (2) corruption and political instability, dearth of capital, outdated technology and low levels of production, (3) poor health care, low life expectancy and high growth rate of population, (4) difficulties related to social, demographic and cul- ture. All of which hindered the development of these essential projects. Literature review and case studies identified 45 challenges that obstruct the development of (MCPs) in developing countries. These challenges were classified into four categories of Engineering Challenges, Human Development Challenges, Managerial and Political Challenges and Sustainability Challenges. Towards overcoming these challenges and assisting governments in developing countries developing (MCPs), the research recommends the following strategies. 


\section{Strategies for Education and Training:} Governments in developing countries have to perceive that providing quality education and professional training is a key driver towards sustainable development and prosperity. Higher percentage of the countries' (GDP) has to be spent to improve education, research and development. This will help equipping human resources with state-of-the-art knowledge and technical expertise needed to overcome the engineering and human development challenges of delivering (MCPs) in developing countries. In addition, offering competitive packages and job opportunities will attract scientists and bright students who completed their higher studies to remain / return back to benefit their countries.

Strategies for Policy, Economy, Technolgy, Infrastructure and Production: A number of stratgies have to adopted by governments in developing countries to improve their situation and increase the chance of developing successful (MCPs). These stratrgies include establishing political stability, eradicating corruption, encouraging ecomomic, and technological development, constructing infrasturcture facilities and increaseing productivity. This will be reflected positivly on improving pubic morality and encouraging people to create ideas that lead to growth and improvement. In addition, these strategies will encourage internal and external investment and secure financial resources needed for developing (MCPs) and reduce the heavy dependency on low agricultural production and decrease the level of unemployment and increase (GDP).

- Strategies for Healthcare, Life Expectancy and Growth Rate of Population: Developing countries have to fight a battle against malnutrition, diseases and ill-health care. Governments in developing are responsible for pro- viding their people with appropriate health care and services, safe drinking water and sanitation facilities. In addition, increasing the percentage of (GDP) spent on improving the health care sector will provide hospitals with sufficient doctors and facilities for the number of inhabitants of these countries and consequently increase people's life expectancy, decreasing death rate of babies at birth and in early infancy. Furthermore, through adopting the abovementioned strategies, the high growth rate of developing countries will be an advantage to these countries and lifeblood towards developing (MCPs).

- Strategies for Society, Demography and Culture: Governments in developing countries, which often ruled by the Military, are encouraged to support democratic transition and activate the role of civil society organisations and cultural change. This will help building trust between governments and their societies in addition to improving people's attitude towards adapting to challenges facing their countries. Moreover, these strategies will change politicians' corruption and misuse of their power as well as reduce the frauds, dishonesty and embezzlements that are very common in governmental departments. All of which assist in overcoming the political and managerial challenges of developing (MCPs) in developing countries.

\section{References}

Al-Maghraby, R. (2012). Mega Projects on Egypt's Horizon. PM World Journal, I, (3).

[Online]. Available from: http://pmworldjournal. net $/$ ?article=mega-projects-on-egyptshorizon (Accessed 21 April 2013).

Altman, J. (2005). Overcoming Mega Project Challenges. Construction Executive Surety Bonding, 24-26. [Online]. Available from: http://suretyinfo.org/news_room/products/ ABC_05_Full.pdf (Accessed 21 April 2013).

Baloyi, L. and Bekker, M. (2011). Causes of construction cost and time overruns:

The 2010 FIFA World Cup stadia in South Africa. Acta Structilia, 18 (1), 51-67.

Beilfuss, R. and Dos Santos, D. (2001). Patterns of Hydrological Change in the

Zambezi Delta, Mozambique. Working Paper No. 2. Program For The Sustainable Management of Cahora Bassa Dam and the Lower Zambezi Valley. [Online]. Available from: http://www. xitizap.com/zambeze-hydrochanges.pdf (Accessed 25 May 2013).

Best, R. and De Valence, G. (1999). Getting it Right at the Start. In: Rick, B. and Valence, G. (eds.) Building in Value: Pre-Design Issues, John Wiley \& Sons Inc., New York.

Bobrova V., Kalvina J. (2004). Economic: Educational the allowance. Orenburg: GOU OGU, 208

Brockmann, C. and Girmscheid, G. (2007). Complexity of megaprojects, In:

Proceedings of CIB World Building Congress 2007 “Construction for Development”; Cape Town 14-17 May 2007; Eds. Haupt, Th., Milford, R.; Publ. CIB, Rotterdam ISBN 1-920-01704-6, 219-230

Bruzelius, N., Flyvbjerg, B. and Rothengatter, W. (2002). Big Decisions, Big Risks. Improving Accountability in Mega Projects. Transport Policy, 9, 143-154.

Capka, R. J. (2004) Megaprojects - They Are a Different Breed., Public Roads, 68(1), 2-9.

CBC News. (2012). "Vladivostok locals get no benefit from APEC summit”. CBC News. September 7, 2012.

Chileshe, N. and Haupt, T.C. (2007). Industry and Academia Perceptions of Construction Management Education - the case of South Africa. The Journal for Education in the Built Environment, 2(2), 85-114. 
Cohen,B. (2006). Urbanization in developing countries: Current trends, future

projections, and key challenges for sustainability. Technology in Society 28, 63-80.

Connexions (2012). Characteristics of Developing countries. [Online]. Available from http:// cnx.org/content/m22818/latest. (Accessed 26 June 2012).

Deputy, E.K. (2011). Designed to Deceive: President Hosni Mubarak's Toshka Project. [Online]. Available from: http://repositories. lib.utexas.edu/bitstream/handle/2152/ETDUT-2011-05-3121/DEPUTY-MASTERS-REPORT. pdf? sequence $=1$ (Accessed 26 June 2012).

Dollerya, B. and Worthingtonb, A. (1996). Economic growth and political stability in

South Africa: Possible Australian policy initiatives. Australian Journal of International Affairs. Australian Journal of International Affairs, 50 (2), 189-197

Economic Concepts. (2013). Common Characteristics of Developing/Third World

Countries. [Online]. Available from: http:// www.economicsconcepts.com/common characteristics_of_developing_countries. htm (Accessed 21 April 2013).

Economics. (2010). Characteristics of Developing Countries. 17, (2). [Online]. Available from: http://economydetail. blogspot.com/2010_02_01_archive.html

Fearnside, P.M. 2006. Dams in the Amazon: Belo Monte and Brazil's Hydroelectric

Development of the Xingu River Basin. Environmental Management 38(1): 16-27.

Field, B. and Ofori, G. (1988). Construction and economic development - a case study. Third World Planning Review, 10(1), 41-50.

Flyvbjerg, B., Bruzelius, N. and Rothengatter, W. (2003). Megaprojects and Risk: An Anatomy of Ambition. Cambridge: Cambridge University Press.

Frick, K.T. (2006). The cost of the technological sublime: daring ingenuity and the new Sand Francisco-Oakland Bay Bridge: in Priemus, H. Flyvbjerg, B. and van Wee, B. (Eds.) Decision-Making on Mega-Projects: CostBenefit Analysis, Planning and Innovation, Cheltenham: Edward Elgar Publishing Limited, $239-262$.

Fry, M. J. (1998). Saving, Investment, Growth, and Financial Distortions in the Pacific Basin and Other Developing Areas. International Economic Journal, 12, Spring, 1-24.
GAP (2011). GAP and UNDP Sustainable Development Program. [Online]. Avaliable from: http://www.gap.gov.tr/projects-andactivities/gap-and-undp-sustainabledevelopment-program (Accessed 25 May 2013).

Georgieva, T.M. (2012). Research Infrastructure megaproject (RIMPS) Management

in an ecosystem perspective: Literature Review. Organisation, Technology and Management in Construction: International Journal, 3 (2), 333-347.

Grun, 0. (2004). Taming Giant Projects: Management of the Multi-organisation Enterprises, (Berlin: Springer).

Haynes, W. (2002). Transportation at the Millennium: In Search of a Megaproject Lens. Review of Policy Research, 19, 62-64.

Hernandez, D. (2012). Mexico cancels megaresort project near Baja California reef

[Online]. Available from: http://latimesblogs. latimes.com/world_now/2012/06/mexicocabo-pulmo-reserve-project-canceled.html (Accessed 22 April 2013).

Hopkinson, M. (2007). Ten Causes of Megaproject Failure. The APM Project Management Conference, The Business of Projects The Brewery conference centre, London, 3031 October 2007.

Human Development Report (2011). [Online]. Available from: http://hdr.undp.org/en/ media/HDR_2011_EN_Table1.pdf (Accessed 22 April 2013).

Hussein, J. and Karimin, S. (2006). Managing Mega Projects - The Experiences of KLIA. Master Builders, 4th Quarter, 68-73.

Jia, G., Yang, F., Wang, G., Hong, B. and You, R. (2011). Study of mega project from a perspective of social conflict theory. International Journal of project management, 26, 817-827.

Kardes, I., Ozturk, A., Cavusgil, T. and Cavusgil, E. (2013). Managing global megaprojects: Complexity and risk management. International Business Review. [Online]. Available from: http:// ac.els-cdn.com/So969593113000048/1s2.0-Sog69593113000048-main. pdf?_tid=8b995cco-ab42-11e2-b4ffoooooaabof6b\&acdnat $=1366631487$ b61e1ca3def1e7335268f2d768ecc445.

Mansur, K., Mamalakis, M. and Idris,S. (2011). Savings, Investment \& FDI Contribution
To Malaysian Economic Growth In The Globalization Era. International Business \& Economics Research Journal, 2(8), 1-14.

Keegan, A. (2004). Transformational leadership in a project-based environment: a comparative study of the leadership styles of project managers and line managers. International Journal of Project Management, 22, 609-617.

Kerzner, H. (2006). Project Management. John Wile and Sons.

Khan, R. A. (2008). Role of construction sector in economic growth: Empirical evidence from Pakistan economy', in Proceedings of the First International Conference on Construction in Developing Countries (ICCIDC), Karachi, Pakistan, August 2008, 279-290.

Kintu, A.B. (2008). Characteristics of Developing Countries. [online]. Available from: http:// www.shvoong.com/social-sciences/1758902characteristics-developing-countries/ (Accessed 22 April 2013).

Koen, D. and Theron, F. (2008). Innovative Design Management And Development Control Case Study: Nelson Mandela Bay Metropole South Africa, In Proceedings of the joint CIB Wo96 Architectural Management and CIB TG49. Architectural Engineering Conference held in conjunction with the 8th Brazilian Workshop on Building Design Management, University of São Paulo, Brazil, 4-8 November 2008. [Online]. Available from: http://www. irb.fraunhofer.de/CIBlibrary/search-quickresult-list.jsp?A\&idSuche $=C I B+D C 10477$ (Accessed 22 April 2013).

Kumar, A. (2012). Major Characteristics of Developing Countries. [Online]. Available from: http://web.uvic.ca/ kumara/ econ420/characteristics-dev.pdf (Accessed 26 June 2012).

Little, R.G. (2011). The Emerging Role of Public Private Partnerships in Mega-Project Delivery. Public Works Management and Policy, 16(3) 240-249.

Loosemore, M., Dainty, and Lingard, H. (2003). Human Resource Management in

construction Projects: Strategic and Operational Approach. Oxford, Spon Press.

MacPherson, S. J., Kelly, J. R. and Webb, R. S. (1993). How Designs Develop:

Insights from Case Studies in Building Engineering Services." Journal of Construction Management and Economics. 11(6), $475-485$ 
Megaproject Cost Action. 2012. [1/08/2012].

Merco Press. (2013). Lack of political support freezes Chile's biggest multi-dam project. [Online]. Available from: http://newsle.com/ article/o/32006284/

Moohebat, M.R., Asem, A. and Jazi, M.D. (2010). A Comparative Study of Critical Success Factors (CSFs) in Implementation of ERP in Developed and Developing Countries. International Journal of Advancements in Computing Technology, 2 (5), 99-110.

Mthalane, D., Othman, A.A.E. and Pearl, R.G. (2007). The economic and social impacts of Site accidents on the South African society. In J.J.P. Verster and H.J. Marx (eds), in Proceedings of the 5 th Post Graduate Conference on Construction Industry Development, Bloemfontein, South Africa, March 2008, 1-10.

Naidoo, N., Pillay, T., Osman, M., Thevan, P., Garaba, S. and Othman A.A.E. (2009). The Future of Construction Education In South Africa: Investigating the Competency of Construction Management Graduates at the University of KwaZulu-Natal. Proceedings of the 2nd Quantity Surveying Conference, Durban, South Africa, 16 October 2009, 151-167.

Nkado, R.N. (2000). Competencies of Professionals Quantity Surveyors in a Developing Economy. 2nd International Conference on Construction in Developing Countries: Challenges facing the construction industry in developing countries. Gaborone: Botswana, 15-17 November 2000.

Othman, A.A.E. and El-Gendawy, A. H. S. (2012). Public-Private Partnership for Lean Sustainable Development in Construction. Journal of Construction Project

Management and Innovation, 2(2), 377-402.

Othman, A.A.E., Hassan, T. M., and Pasquire, C.L. (2004). Drivers for Dynamic Brief Development in Construction. Engineering, Construction and Architectural Management, 11(4), 248-258.

Othman, A.A.E. (2012). A Study of the Causes and Effects of Contractors' Non-Compliance with the Health and Safety Regulations in the South African Construction Industry. Journal of Architectural Engineering and Design Management, 8(3), 180-191.

Pakistan \& Gulf Economist (1999). Settlement of Tarbela Dam affectees claims. [Online]. Available from: http://www. pakistaneconomist.com/issue1999/ issue $30 / f \&$ m4.htm (Accessed 28 May 2013).

Procaccini, C., Lea-Cox, A. and Scheffer, W.D.H (2012). Challenges of E\&P Megaproject Delivery. [Online]. Available from: http://www.sbc.slb.com/Our_Ideas/ Energy_Perspectives/Summer12_Content/ Summer\%2012_Challenges.aspx (Accessed 22 April 2013).

Ramburan, S. and Othman, A.A.E. (2007) Improving the Skills of Physically Disable Persons for Economic and Social Development in South Africa. Proceedings of the International Conference on Sustainable Human Settlements for Economic and Social Development, Zambezi Sun International Hotel, Livingstone, Zambia, 2-5 May 2007, 494-512.

Ruuska, I., Artto, K., Aaltonen, K. and Lehtonen, P. (2009). Dimensions of distance in a project network: Exploring Olkiluoto 3 nuclear power plant project. International Journal of Project Management, 27, 142-153.

Rwelamila, P.M.D. (2007). Construction Project Management Education Programmes in South Africa- addressing the gap. 2nd International Conference World of Construction Project Management. TU Delft: Netherlands.

Sanderson, J. (2012). Risk, uncertainty and governance in megaprojects: A critical discussion of alternative explanations. International Journal of Project Management, $30,432-443$

Shore, B. and Cross, B.J. (2005). Exploring the role of national culture in the management of large scale international science projects. International Journal of Project Management, $23,55-64$.

Stoddart-Stones, R. (1988). Development of project management systems for major projects. International Journal of Project Management, 6, 34-38.

Sturup, S. (2009). Megaprojects and Governability. World Academy of Science, Engineering and Technology, 54.

Tenah, K. (1985). The Construction Management Process. 1ST Ed., Reston

Publishing Company Inc., Virginia.

The Egyptian Gazette.(2011). Heavy losses cited in Toshka project. [online].

Available from: http://213.158.162.45/ egyp tian/ ?action $=$ news $\&$ id $=15948$

Toor, S. R. and Ogunlana, S. O. (2006) Conquering The Construction Battle: Overcoming the Problems on Large Construction Projects in a Developing Economy. Proceedings of the International Conference in Built Environment (ICiBE), Kuala Lumpur, Malaysia.

Van Marrewijk, A., Clegg, S. R., Pitsis, T. S. and Veenswijk, M. (2008). Managing Public-Private Megaprojects: Paradoxes, Complexity, and Project Design. International Journal of Project Management, 26, 591-600.

UNESCO. (2012). State of Conservation (SOC), Historic Centre of Saint Petersburg and Related Groups of Monuments. [Online]. Available from: http://whc.unesco.org/en/ soc/268 (Accessed 22 April 2013).

Walta info. (2013). Do reasons against mega projects in Ethiopia cut ice?. [Online]. Available from: http://www.waltainfo.com (Accessed 15 March 2013).

WDR. (2012). World Development Report. [Online]. Available from: http://econ. worldbank.org

Witular, R. A. (2009). Special Report: 'Made in China' poses as Rl's pride”. The Jakarta Post. [Online]. Available from: http://www. thejakartapost.com/news/2009/06/10/ special-report-made-china039-poses-rio39spride.html (Accessed 23 April 2013).

World Bank (2012). Annual Report 2012. [Online]. Available from: http://web.worldbank.org (Accessed 23 April 2013).

Yin, R. (1989). Case Study Research: Design and Methods. Sage Publication

Zeybek, H. and Kaynak, M. (2008). Role of Mega Projects in Sustainable Urban

Transport in Developing Countries: the Case of Istanbul Marmaray Project. Proceedings of Codatu XIII: Sustainable Development Challenges of Transport in Cities of the Developing World: Doing what works, 12-14 November 2008, Ho Chi Minh City, Vietnam. [Online]. Available from http://www. codatu.org/english/conferences/codatu13/ CodatuXIII-CDrom/codCD-Zeybek.pdf (Accessed 20 March 2013). 
Table (1) Name, Location, Estimated Budget \& Development Status of Case Studies

Dams, Canals, Hydroelectric and Water Infrastructure Projects

\begin{tabular}{l|l|l|l|l}
\hline Case No. & Project Name & Location & $\begin{array}{l}\text { Estimated } \\
\text { Budget }\end{array}$ & Development Status \\
\hline Case (1) & Toshka Project & Egypt & US\$87 Billion & Under Development \\
\hline Case (2) & Chile’s biggest multi-dam project & Chile & US\$7 Billion & Under Development \\
\hline Case (3) & Mexico mega-resort Development & Mexico & US\$1.5 Billion & Halted \\
\hline Case (4) & South-eastern Anatolia Project & Turkey & US\$22 Billion & Under Development \\
\hline Case (5) & Belo Monte Dam & Brazil & US\$18.5 Billion & Under Development \\
\hline Case (6) & Tarbela Dam & Pakistan & US\$1.5 Million & Developed \\
\hline Case (7) & Cahora Bassa Dam & Mozambique & US\$2.2 Billion & Developed \\
\hline Case (8) & Great Manmade River & Libya & US\$25 Billion & $\begin{array}{l}\text { Likely cancelled due to } \\
\text { political instability and } \\
\text { overthrow of the regime } \\
\text { that sponsored it }\end{array}$
\end{tabular}

Planned Cities and Urban Renewable Projects

\begin{tabular}{|c|c|c|c|c|}
\hline Case (9) & Egypt Space Programmes & Egypt & US\$ 21 Million & Halted \\
\hline Case (10) & The Western Desert New Axis & Egypt & Not Available & Halted \\
\hline Case (11) & 2010 FIFA World Cup Stadia & South Africa & US\$ 2 Billion & Developed \\
\hline Case (12) & Nelson Mandela Bay Metropole & South Africa & Not Available & Under Development \\
\hline Case (13) & Historical Sites & Ethiopia & Not Available & Halted \\
\hline Case (14) & Lakhta Centre & Russia & US\$2.56 Billion & Under Development \\
\hline Case (15) & 400 Housing Projects & $\begin{array}{l}\text { United Arab } \\
\text { Emirates }\end{array}$ & US\$ 4.4 Billion & Developed \\
\hline \multicolumn{5}{|c|}{ Bridge and Highway Projects } \\
\hline Case (16) & Suramadu Bridge & Indonesia & US\$ 445 Million & Developed \\
\hline Case (17) & Egypt - Saudi Arabia Bridge & $\begin{array}{l}\text { Egypt \& Saudi } \\
\text { Arabia }\end{array}$ & US\$ 4 Billion & Cancelled \\
\hline Case (18) & Russky Bridge & Russia & US\$ 1 Billion & Developed \\
\hline Case (19) & Baluarte Bridge & Mexico & US\$ 118 Million & Developed \\
\hline Case (20) & Bandra-Worli Sea Link & India & US\$ 16 Billion & Developed \\
\hline Case (21) & Hangzhou Bay Bridge & China & US\$1.42 Billion & Developed \\
\hline Case (22) & Lahore Ring Road & Pakistan & US\$ 11 Billion & Developed \\
\hline \multicolumn{5}{|c|}{ Rail and Rapid Transit Projects } \\
\hline Case (23) & Beijing Subway & China & Not Available & Developed \\
\hline Case (24) & Bucharest Metro & Romania & US\$ 954 Million & Developed \\
\hline Case (25) & Cairo Metro (Phase 1) & Egypt & US\$ 62 Million & Developed \\
\hline Case (26) & Greater Kuala Lumpur Mass Rapid Transit & Malaysia & Not Available & Launched on 2011 \\
\hline Case (27) & Tehran Metro & Iran & US\$ 18 Billion & Developed \\
\hline
\end{tabular}




\begin{tabular}{l|l|l|l|l}
\hline \multicolumn{5}{|c}{ Airport Projects } \\
\hline Case (28) & 2nd Bangkok International Airport & Thailand & US\$4 Billion & Developed \\
\hline Case (29) & Kuala Lumpur International Airport & Malaysia & US\$3.5 Billion & Developed \\
\hline Case (30) & Guangzhou Baiyun International Airport & China & US\$3 Billion & Developed \\
\hline Case (31) & Kuala Namu International Airport & Indonesia & US\$2.54 Trillion & Under Development \\
\hline Case (32) & Bandung Majalengka International Airport & Indonesia & US\$900 Million & Under Development \\
\hline Case (33) & King Shaka International Airport & South -Africa & US\$900 Million & Developed \\
\hline Case (34) & Long Thanh International Airport & Vietnam & US\$10 Billion & Under Development \\
\hline Case (35) & Indira Gandhi International Airport & India & US\$3 Billion & Developed \\
\hline Case (36) & Clark International Airport & Philippines & US\$1.2 Billion & Developed \\
\hline
\end{tabular}

\section{Appendix (A)}

Table (5) Classification Categories of (MCPs) in Developing Countries

\begin{tabular}{|c|c|c|c|c|c|c|c|c|c|}
\hline \multirow{2}{*}{\multicolumn{2}{|c|}{ (MCPs) Challenges }} & \multicolumn{2}{|c|}{$\begin{array}{l}\text { Engineering } \\
\text { Challenges }\end{array}$} & \multirow[t]{2}{*}{$\begin{array}{l}\text { Human } \\
\text { Development } \\
\text { Challenges }\end{array}$} & \multicolumn{2}{|c|}{$\begin{array}{l}\text { Managerial and } \\
\text { Political } \\
\text { Challenges }\end{array}$} & \multicolumn{3}{|c|}{$\begin{array}{l}\text { Sustainability } \\
\text { Challenges }\end{array}$} \\
\hline & & $\frac{\overline{.0}}{\bar{y}}$ & 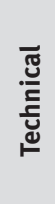 & & 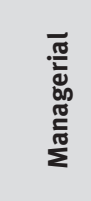 & ত্ّே: & 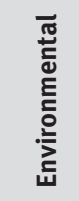 & 吾 & 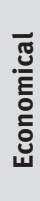 \\
\hline 1 & $\begin{array}{l}\text { Lack of design knowledge and experience } \\
\text { related to (MCPs) }\end{array}$ & $\mathrm{X}$ & & & & & & & \\
\hline 2 & $\begin{array}{l}\text { Lack of professional expertise and full } \\
\text { consideration of technical requirements }\end{array}$ & & $\mathrm{X}$ & & & & & & \\
\hline 3 & $\begin{array}{l}\text { Misunderstanding and partial achievement of } \\
\text { project objectives }\end{array}$ & $\mathrm{x}$ & & & $\mathrm{X}$ & & & & \\
\hline 4 & Lack of financial resources and venture capital & & & & $\mathrm{x}$ & & & & $\mathrm{x}$ \\
\hline 5 & $\begin{array}{l}\text { Lack of research capacity and business } \\
\text { innovation }\end{array}$ & & $\mathrm{X}$ & & $\mathrm{x}$ & & & & \\
\hline 6 & Missing Intermediary bodies & & & & $\mathrm{x}$ & & & $\mathrm{X}$ & \\
\hline 7 & Unfavourable regulatory framework & & & & $\mathrm{x}$ & & & & \\
\hline 8 & $\begin{array}{l}\text { Lack of providing and managing high- } \\
\text { qualified human resources }\end{array}$ & & & $x$ & & & & & \\
\hline 9 & Bureaucracy and Corruption practices & & & & $\mathrm{x}$ & $\mathrm{x}$ & & & \\
\hline 10 & Lack of political support & & & & & $\mathrm{x}$ & & & \\
\hline 11 & $\begin{array}{l}\text { Difficulty resourcing the right skills and } \\
\text { matching with project demands and } \\
\text { geography }\end{array}$ & & & $\mathrm{x}$ & & & & & \\
\hline 12 & $\begin{array}{l}\text { Lack of experienced staff to accept critical } \\
\text { roles which they are not prepared for }\end{array}$ & & & $\mathrm{X}$ & $\mathrm{x}$ & & & & \\
\hline
\end{tabular}




\begin{tabular}{|c|c|c|c|c|c|c|c|c|c|}
\hline 13 & $\begin{array}{l}\text { Governance decisions fail to strike a balance } \\
\text { between short- and long-term objectives and } \\
\text { effective risk mitigation }\end{array}$ & & & & $X$ & & & & \\
\hline 14 & $\begin{array}{l}\text { Improper identification and engagement } \\
\text { of various stakeholder groups in the early } \\
\text { project phases }\end{array}$ & & & & $X$ & & & $X$ & \\
\hline 15 & $\begin{array}{l}\text { Tight service market and lack of internal } \\
\text { capacity }\end{array}$ & & & $X$ & $X$ & & & & \\
\hline 16 & $\begin{array}{l}\text { Improper implementation of project } \\
\text { management processes and training of key } \\
\text { project staff }\end{array}$ & & & & $X$ & & & & \\
\hline 17 & $\begin{array}{l}\text { Lack of available on-site skilled workers or } \\
\text { local labour forces. }\end{array}$ & & & $X$ & & & & & \\
\hline 18 & Lack of properly trained on-site supervisors & & & $X$ & $X$ & & & $X$ & \\
\hline 19 & $\begin{array}{l}\text { Huge numbers of people and organisations of } \\
\text { different specialties involved in mega projects } \\
\text { development }\end{array}$ & & & & $X$ & & & $X$ & \\
\hline 20 & $\begin{array}{l}\text { Ill-defined rules and procedures as well as } \\
\text { inappropriate use of prior experience to } \\
\text { review contingencies }\end{array}$ & & $X$ & & $X$ & & & & \\
\hline 21 & $\begin{array}{l}\text { Inadequate communication at all levels and } \\
\text { poor coordination interface management } \\
\text { between project stakeholders }\end{array}$ & & & & $X$ & & & $X$ & \\
\hline 22 & Lack of quality front-end planning & & $X$ & & $X$ & & & & \\
\hline 23 & $\begin{array}{l}\text { Improper decision making and overlooking } \\
\text { specialists and stakeholders consultation } \\
\text { during the decision making process }\end{array}$ & $X$ & $X$ & & $X$ & & & & \\
\hline 24 & Lack of construction material availability & $X$ & $\mathrm{X}$ & & $X$ & & & & \\
\hline 25 & $\begin{array}{l}\text { Ignorance of health and safety considerations } \\
\text { as well as the absence of activating health } \\
\text { and safety acts }\end{array}$ & & & & $X$ & & & $X$ & \\
\hline 26 & Weak governance of project management & & & & $X$ & & & & \\
\hline 27 & Political imperatives and authority misuse & & & & $X$ & $X$ & & & \\
\hline 28 & Lack of exploiting uncertainties & & & & $X$ & & & & \\
\hline 29 & Project authorisation pressures on individuals & & & & $X$ & & & & \\
\hline 30 & $\begin{array}{l}\text { Failure to invest sufficiently before the } \\
\text { project's main authorisation point }\end{array}$ & & & & $X$ & & & & $x$ \\
\hline 31 & $\begin{array}{l}\text { Unachievable targets cause sub-optimal } \\
\text { project outcomes }\end{array}$ & & & & $X$ & & & & \\
\hline 32 & $\begin{array}{l}\text { Lack of efficiency and effectiveness of the } \\
\text { Project Management process }\end{array}$ & & & & $X$ & & & & \\
\hline 33 & $\begin{array}{l}\text { Naïve risk analysis and inappropriate } \\
\text { identification of the project consequences }\end{array}$ & & & & $X$ & $X$ & & & $X$ \\
\hline 34 & $\begin{array}{l}\text { Inappropriate behaviour of the client } \\
\text { organisation }\end{array}$ & & & & $X$ & $X$ & & & \\
\hline 35 & $\begin{array}{l}\text { Lack of considering environmental } \\
\text { requirements and preserving historical sites } \\
\text { and natural reserve }\end{array}$ & & & & $X$ & & $X$ & & \\
\hline
\end{tabular}




\begin{tabular}{|c|c|c|c|c|c|c|}
\hline 36 & $\begin{array}{l}\text { Ineffective project management and poor use } \\
\text { of experience and competency of client and } \\
\text { contractor organisations }\end{array}$ & $X$ & $\mathrm{X}$ & & $X$ & \\
\hline 37 & $\begin{array}{l}\text { Lack in managing complexities of work } \\
\text { content and work processes }\end{array}$ & & $\mathrm{X}$ & & $X$ & \\
\hline 38 & $\begin{array}{l}\text { Lack of strategic project planning and } \\
\text { ineffective leadership }\end{array}$ & & $\mathrm{X}$ & & $X$ & \\
\hline 39 & Leadership problems & & & & $X$ & \\
\hline 40 & Lack of managing social project complexity & & & & & $X$ \\
\hline 41 & Lack of managing cultural project complexity & & & & & $X$ \\
\hline 42 & $\begin{array}{l}\text { Inappropriate level of scientific and } \\
\text { technological knowledge and application } \\
\text { required }\end{array}$ & $X$ & $X$ & & $X$ & \\
\hline 43 & $\begin{array}{l}\text { Lack of providing quality education and } \\
\text { professional training programmes }\end{array}$ & & & $\mathrm{X}$ & $\mathrm{X}$ & \\
\hline 44 & Political tension between countries & & & & $\mathrm{X}$ & \\
\hline 45 & $\begin{array}{l}\text { Stakeholders change project requirements at } \\
\text { later stages of the project life cycle }\end{array}$ & $X$ & $\mathrm{X}$ & & $X$ & \\
\hline
\end{tabular}

\section{Appendix (B)}

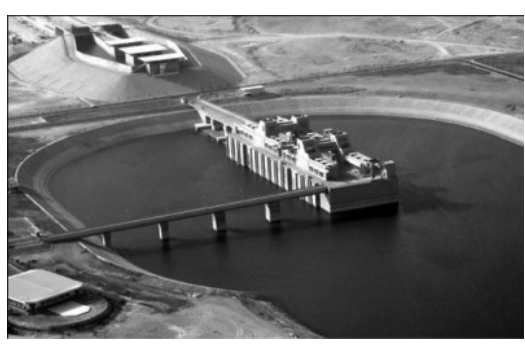

Toshka Project, Egypt

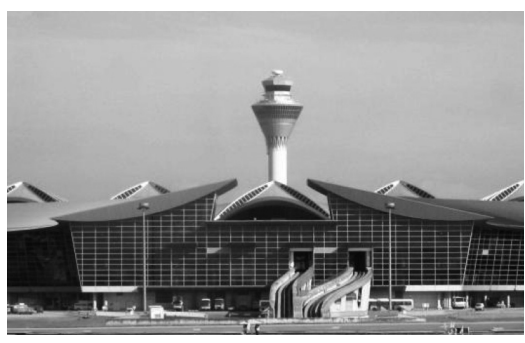

Kuala Lumpur International Airport (KLIA) Project, Malaysia

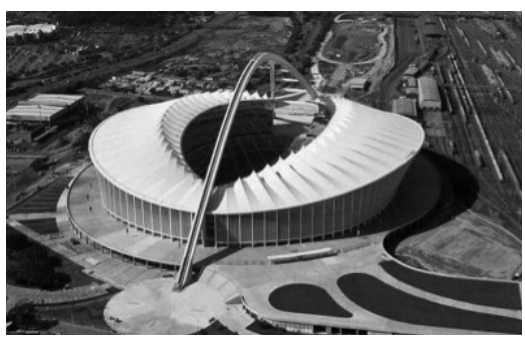

2010 FIFA World Cup Stadium in Durban, South Africa

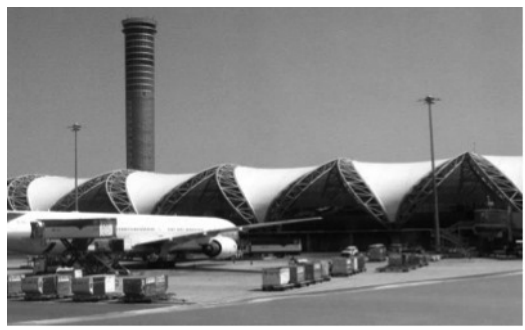

Second Bangkok International Airport, Thailand

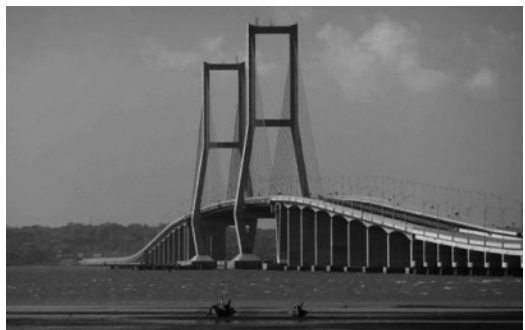

Suramadu Bridge, Indonesia 